\title{
Анализ правовых аспектов конфликта в Таджикистане и его разрешения
}

\section{Раджабов C.A.*}

Следует отметить, что анализ правовых аспектов вооружённого конфликта в Республике Таджикистан (РТ) является сложным теоретическим вопросом и имеет важное практическое значение для его разрешения.

Согласно праву вооружённых конфликтов (иногда эта отрасль права называется правом войны или международным гуманитарным правом) все конфликты делятся на международные и немеждународные.

Основными международно-правовыми документами, определяюшими типы указанных вооружённых конфликтов, являются четыре Женевские конвенции о зашите жертв войны от 12 августа 1949 г. и два Дополнительных протокола к ним от 8 июня 1977 г. Республика Таджикистан присоединилась к названным документам 13 января 1993 г. и взяла на себя обязательства по имплементации содержашихся в них норм в своё национальное законодательство и по их соблюдению.

В Женевских конвенциях 1949 года и Дополнительных протоколах к ним содержатся объективные критерии квалификации вооруженных конфликтов.

Согласно этим международным документам к ситуациям международного вооружённого конфликта относятся:

1. вооружённый конфликт между двумя или несколькими государствами ${ }^{1}$;

2. вооружённый конфликт, в котором народы ведут национальноосвободительную войну в осушествление права на самоопределение против колониального господства, иностранной оккупации и расистского режима².

Следует отметить, что со времени окончания Второй мировой войны большая часть вооружённых конфликтов носила немеждународ-

\footnotetext{
- Раджабов Саитумбар Адинаевич - к.ю.н., доцент.

' См.: Ст. 2 (2), общую для четырёх Женевских конвенций 1949 г.

${ }^{2}$ См.: Ст. 1 (4) Дополнительного протокола І от 1977г.
} 
ный характер, т.е. происходила не между государствами, а внутри самих государств. Эти братоубийственные конфликты (гражданские войны) причинили немало страданий и повлекли большое количество жертв.

Конфликты немеждународного характера в зависимости от степени интенсивности и масштаба военных действий подразделяются на два вида.

Первый внд немеждународного конфликта, в котором друг другу противостоят, с одной стороны, правительственные вооруженные силы и, с другой, антиправительственные вооруженные силы или организованные вооруженные группы. При этом последние должны:

1. находиться под ответственным командованием;

2. осуществлять контроль над частью территории страны;

3. этот контроль должен позволять им осуществлять непрерывные и согласованные военные действия;

4. применять Протокол $\mathrm{II}^{3}$.

Второй вид - это когда конфликт не достиг данной степени интенсивности, однако, все же представляет собой внутренний вооруженный конфликт. Этот вид конфликта немеждународного характера подпадает под действие статьи 3, обшей для всех Женевских конвенций о защите жертв войны 1949 года, документов по правам человека и внутригосударственных норм.

В данном виде конфликта, вероятно, отсутствуют такие критерии как, высокая организованность вооруженных групп (хотя определенная степень организации необходима), контроль над территорией (просто присутствие на какой-либо территории не квалифицируется как контроль в смысле Протокола II).

Необходимо сразу же оговориться, что из понятия немеждународного вооруженного конфликта исключаются две ситуации:

а) случаи нарушения внутреннего порядка;

б) возникновение обстановки внутренней напряженности, такие как беспорядки, отдельные и спорадические акты насилия ${ }^{4}$.

К первой относятся такие нарушения общественного порядка, как демонстрации и шествия без заранее согласованного плана, отдельные акции протеста, столкновения и другие аналогичные действия.

Ко второй можно отнести ситуации серьезной политической, религиозной, расовой, социальной, экономической напряженности, кото-

${ }^{3}$ Дополнительный протокол II (далее в ссылках ДП ІІ) от 8 июня 1977 г., ст. 1 (1).

${ }^{4}$ ДП II, ст. 1 (2). 
рые характеризуются следующими признаками: массовые аресты, большое количество задержанных лиц, объявление чрезвычайного положения, заявления об исчезновениях и т.п. ${ }^{5}$

Данные ситуации, в основном, подпадают под действие международного права прав человека и соответствующих положений внутригосударственного права.

Таким образом, сфера применения международного гуманитарного права не распространяется в настояшее время на внутренние беспорядки и ситуации напряженности. Тем не менее, это не значит, что не существует международной правовой зашиты, применимой в таких ситуациях. Эти случаи подпадают под действие документов по правам человека.

Относительно ст. 3, следует подчеркнуть, что она является краеугольным камнем гуманитарного права, применяемого в период немеждународных вооруженных конфликтов. Она является крупным достижением в области международного гуманитарного права.

Статья 3, общая для всех Женевских конвенций о защите жертв войны 1949 года, считается минимальным стандартом, который должен соблюдаться сторонами в ходе вооруженного конфликта любого характера, и ее положения считаются нормами обычного права ${ }^{6}$.

Подведем некоторый итог сказанному. Прежде всего, вооруженные конфликты характеризуются наличием юридического статуса противоборствующих сторон.

В международных вооруженных конфликтах участники конфликта - это суверенные государства, либо государство и народы, ведушие борьбу в осуществление своего права на самоопределение.

В немеждународных вооруженных конфликтах участники боевых действий - это не суверенные государства, а правительство одного государства, с которым вступили в конфликт одна или более вооруженные группировки на территории этого государства.

Одним из определяющих факторов для квалификации международных и немеждународных вооруженных конфликтов является государственная граница. При первых видах конфликтов происходит нарушение территориальной целостности государства, в то время как во время вторых действия ведутся, в основном, внутри территории государства.

'См.: Комментарий к Допопнитепному протокалу II. - Москва, МККК, 1998. - С. 68-69.

${ }^{\circ}$ Сим.: Дело Международного суда «Никарагуа против США». 
Следует особо подчеркнуть, что гуманитарное право не затрагивает юридического статуса находящихся в конфликте территорий, и применение его норм не означает признания субъектом международного права стороны, которая не может на это претендовать на других основаниях.

Перейдя от теории к практике, рассмотрим ситуацию вооруженного конфликта в Таджикистане в правовом измерении.

Стремительные перемены, связанные с распадом Советского Союза в 1991 году, привели к развалу политических, экономических и социальных структур некогда мощной державы, создав тем самым благоприятную почву для борьбы за власть, ее перераспределения и изменения характера. Непланомерный и нецивилизованный переход к рыночной экономике привел к обнищанию народа, падению производства, безработице, разрушению системы социального обеспечения, здравоохранения и образования. Все это в сочетании со многими другими факторами (геополитическим, исламским, региональным и т.д.) ввергло Таджикистан в пучину гражданской войны, которая унесла жизни тысяч людей, создала проблемы с беженцами и перемещенными лицами, причинила колоссальный экономический ущерб и усугубила и без того тяжелое положение дел в Республике.

До начала гражданской войны ситуация в Республике Таджикистан претерпела ряд изменений. Сложившуюся ситуацию можно охарактеризовать как нарушение внутреннего порядка и возникновение обстановки внутренней напряженности. Примером могут служить февральские события 1990 года в городе Душанбе, когда демонстранты требовали отставки первого секретаря ЦК Компартии Таджикистана К.Махкамова, что сопровождалось отдельными и спорадическими актами насилия, поджогами транспортных средств, грабежами магазинов и т.д.' Тогда власти Республики прибегли к использованию крупных сил милиции и даже внутренних войск, чтобы восстановить порядок в столице страны.

Правовая квалификация данного этапа развития ситуации в Республике, на наш взгляд, была такова: мы имели дело с внутренними беспорядками, и ситуация характеризовалась напряженностью, но еще не шла речь о нарушении норм международного гуманитарного права, т.е. статьи 3, общей для всех Женевских конвенций 1949 года и Дополнительного протокола II 1977 года к ним. Тогда ситуация подпадала

\footnotetext{
${ }^{7}$ См.: Пономарев В., Колокола надежды // «Правда», 10-11.05.1990.
} 
под действие национального права (Конституция РТ и УК), международных и региональных документов по правам человека (Международного билля о правах человека, Заключительного акта Совешания по безопасности и сотрудничеству в Европе и др.).

Ситуация еше больше дестабилизировалась весной 1992 года в результате многодневных митингов и противостояния двух площадей в г.Душанбе - Шахидон и Озоди, что представляло собой проявление противоречий (политических, идеологических, экономических, национально-территориальных, религиозных и др.) в таджикском обществе после получения политической независимости ${ }^{8}$.

На этот раз ситуацию в рамках внутренней напряженности удержать не удалось. Она развилась и переросла в гражданскую войну, что характеризовалось расколом общества на противоборствующие стороны.

Внутреннему вооруженному конфликту на данном этапе были присущи следующие черты: участниками военных действий явились правительственные регулярные силы, проправительственный Народный фронт Таджикистана во главе с Сангаком Сафаровым, с одной стороны, и антиправительственные вооруженные отряды Исламской партии возрождения Таджикистана, Демократическая партия Таджикистана, сторонники Народного движения «Растохез» и общество «Лаъли Бадахшон»-с другой.

По своим объективным и субъективным критериям (непродолжительность и низкая интенсивность боевых действий, неподконтрольность территории со стороны оппозиции и т.д.) сложившуюся ситуацию можно было охарактеризовать как вооруженный конфликт, не носяший международного характера, что автоматически подпадало под действие статьи 3 , общей для всех Женевских конвенций 1949 года о защите жертв войны.

На новом витке напряженности ситуация в Таджикистане характеризовалась такими качественными параметрами, как определенный уровень представительства и организованность вооруженных подразделений Объединенной таджикской оппозиции (ОТО), наличие сформированного оппозиционного правительства со штаб-квартирой в г.Талукане (Афганистан), наличие вертикального подчинения лидеру ОТО Сайиду Абдулло Нури подразделений полевых командиров

${ }^{8}$ См.: Таджикистан в огне. - Душанбе: Ирфон, 1993. - С. 178-185; Г. Хайдаров, И. Имонов. Таджикистан: трагедия и боль народа. Санкт-Петербург: Акционерное общество линко, 1993. С. 74-86. 
(Мирзо Зияева, Мирзохуджы Низомова и др.); издание оппозицией приказов и инструкций, выпуск периодических изданий (газет и журналов); контроль над частью территории государства (Раштская долина, Тавильдаринский район).

Правительство Республики Таджикистан объявило чрезвычайное положение, мобилизовало силы безопасности для борьбы с вооруженными отрядами ОТО.

На данном этапе порог интенсивности боевых действий был достаточно высок, так как ситуация характеризовалась наличием всех критериев, изложенных в части 1 статьи 1 Дополнительного протокола II к Женевским конвенциям 1949 года, а именно: это был конфликт между правительственными и антиправительственными силами; силы оппозиции, находясь под ответственным командованием, осуществляли над частью территории государства такой контроль, который позволял им вести непрерывные и согласованные военные действия и применять Дополнительный протокол II.

Таким образом, вооруженный конфликт немеждународного характера в Таджикистане прошел в своем развитии три стадии:

1. стадия внутренней напряженности и беспорядков на начальном этапе, когда применялись нормы национального законодательства и международного права прав человека;

2. стадия конфликта с низким порогом интенсивности, когда была применима статья 3, общая для всех Женевских конвенций 1949 года;

3. стадия, когда конфликт дошел до самого верхнего порога насилия, когда были применимы нормы Дополнительного протокола II.

27 июня 1997 г. президентом РТ и руководителем ОТО был подписан под эгидой ООН документ, который известен как «Общее соглашение об установлении мира и национального согласия в Таджикистане». Он объединяет пакет из 9 документов (протоколов и соглашений). Этот комплексный документ создавал правовой механизм для разрешения вооруженного конфликта в РТ. Следует отметить, что правительство РТ приняло меры по выполнению свонх международных обязательств, вытекающих из Женевских конвенций 1949 года и Дополнительных протоколов к ним 1977 г. Так, пункт 5 статьи 6 Дополнительного протокола II 1977 года гласит: «По прекращении военных действий органы, находящиеся у власти, стремятся предоставить как можно более широкую амнистию лицам, участвовавшим в вооруженном конфликте, и лицам, лишенным свободы по причинам, связанным 
с вооруженным конфликтом, независимо от того, были ли они интернированы или задержаны».

В полном соответствии с этой правовой нормой и в целях ее реализации Правительство РТ и Комиссия по национальному примирению приняли два важных правовых акта: «Акт о взаимопрощении» и «Закон об амнистии участников политического и военного противостояния в РТ». Кроме того, «Положение о Комиссии по национальному примирению» предусматривало создание четырех подкомиссий, в том числе по правовым вопросам.

Подкомиссия по правовым вопросам состояла из 6 членов и включала равное число представителей от каждой из сторон: Отахон Латифи - председатель подкомиссии (ОТО), Киемиддин Гозиев - член подкомиссии (ОТО), Файзиддин Имомов - член подкомиссии (ОТО), Халифабобо Хомидов - член подкомиссии (Правительство РТ), Зариф Алиев - член подкомиссии (Правительство РТ), Шермахмад Шоев - член подкомиссии (Правительство РТ).

В функциональные обязанности данной подкомиссии входило решение следующих вопросов:

восстановление беженцев и вынужденных переселенцев во всех правах, которыми обладают граждане РТ (включая возвращение им жилья и имущества, сохранение непрерывного трудового стажа), а также непривлечение возвращающихся беженцев и вынужденных переселенцев к уголовной ответственности за участие в политическом противостоянии и гражданской войне;

- осушествление амнистии лиц, участвовавших в гражданском конфликте и политическом противостоянии;

- контроль за осуществлением полного обмена военнопленными, заключенными и освобождением насильно удерживаемых лиц9;

- снятие запретов и ограничений на деятельность политических партий и движений, входящих в ОТО, а также их СМИ, которые будут функционировать в рамках Конституции и действующих законов РТ.

В целях стабилизации политической ситуации и реализации Общего соглашения об установлении мира и национального согласия в Таджикистане по инициативе Комиссии по национальному примирению были приняты Акты об амнистии 1997 и 1999 годов, которые повлияли на судьбы 21.500 осужденных и других лиц, совершивших преступ-

${ }^{9}$ См.: Общее соглашение об установлении мира и национального согласия в Таджикистане. - Душанбе: МНООТ, 1997. - С. 36-42. 
ления, и они были освобождены от уголовной ответственности. 23 августа 2001 г. Маджлиси Намояндагон Маджлиси Оли Республики Таджикистан принял акт «О всеобщей амнистии», согласно которому под амнистию подпадало около 19.000 осужденных и других лиц, совершивших преступления ${ }^{10}$.

Необходимо подчеркнуть, что лица, обвиняемые в соответствии со статьями 63 (террористический акт), 74 (бандитизм), 76 (контрабанда), 96 (кража государственной или общественной собственности в крупных размерах), 104 (умышленное убийство с отягчающими обстоятельствами), 105 (умышленное убийство без отягчающих обстоятельств), 121 (изнасилование), 240, 241 (незаконный оборот наркотических средств) Уголовного кодекса РТ, не подлежали освобождению от наказания и уголовной ответственности согласно п. 4 «Закона об амнистии участников политического и военного противостояния в Республике Таджикистан»" .

Женевские конвенции 1949 года также устанавливают для государств-участников конкретное обязательство «ввести в действие законодательство, необходимое для обеспечения эффективных уголовных наказаний для лиц, совершивших или приказывавших совершить те или иные серьезные нарушения» ${ }^{12}$.

Во исполнение этих обязательств Республикой Таджикистан был разработан новый Уголовный кодекс, который предусматривает наказание за наиболее серьезные нарушения положений Женевских конвенций и Дополнительных протоколов к ним, которые считаются военными преступлениями ${ }^{13}$. Новый УК РТ был введен в действие с 1 сентября 1998 г.

На наш взгляд, без укрепления правовой базы борьбы с преступностью нельзя было обеспечить достижения мира и согласия в стране. С этой целью Президент и Правительство РТ приняли ряд правовых актов, в частности от 2 декабря 1994 г. « О добровольной сдаче и об изъятии оружия, боеприпасов и боевой техники у населения Республики Таджикистан», от 23 сентября 1995 г. «О мерах по усилению борьбы с преступностью, укреплению законности и правопорядка»,

${ }^{10} \mathrm{Cм.:} \mathrm{Бизнес} \mathrm{и} \mathrm{политика,} \mathrm{2001,} 30$ августа.

"См.: Accord № 10, 2001. С. 106-107.

${ }^{12}$ См.: ст. 49, 50, 129, 146 Женевских конвенций 1949 г. соответственно.

${ }^{13}$ См., подробнее: С.А. Раджабов. Военные преступления как наиболее серьезные нарушения норм международного гуманитарного права. - Душанбе, Славянский университет, 2001. - С. 6-7. 
от 21 июля 1998 г. «О дополнительных мерах по усилению борьбы с преступностью в сфере экономики и коррупции», от 11 декабря 1999 г. «О борьбе с коррупцией» и другие.

В 1995-2000 годы были выявлены более 8 тысяч преступлений в сфере экономики, а экономический ушерб составил более 100 млн. американских долларов ${ }^{14}$.

В 1993-2000 годы Группой Пограничных Войск Российской Федерации в Таджикистане было изъято из обрашения около 10 тонн различных наркотических вешеств.

В 1999 году было создано Агентство по контролю над наркотиками при Президенте РТ. Если в 1996 году в РТ было изъято только 8 кт героина, то в 2000 году количество изъятого героина составило 2 тонны.

Борьба правоохранительных органов Республики Таджикистан показала всему миру, что именно пресечение и предупреждение преступности и сохранение социального контроля над ней может привести к стабилизации жизни, потому что именно подобная активная позиция государства всегда выступает основой национального примирения, общественного согласия и разрешения всякого рода конфликтов в обществе.

И последнее. Процесс подготовки и принятия Конституции РТ 1994 года, изменения и дополнения, принятые всенародными референдумами в 1999 и 2003 годах внесли существенный вклад в обеспечение единства, стабильности и мирного развития таджикского общества. Конституция, будучи главным юридическим документом, воплощая в себе начала согласия, мира и единения, является в наибольшей степени актом согласительного характера и обязательным для всех членов общества.

Таким образом, анализ юридических аспектов достижения мира и согласия в Таджикистане показывает, что для успешного разрешения вооруженного конфликта была разработана и осуществлена солидная международная и внутригосударственная правовая база. Все это способствовало разрешению разногласий и противоречий, которые возникали в ходе переговорного процесса в рамках законности, в соответствие с буквой и духом достигнутых договоренностей, в духе уважения прав человека и основных свобод. Следует отметить вклад международных организаций (ООН, ОБСЕ, ОИК), стран Контактной группы (Иран, Афганистан, Казахстан, Кыргызстан, Пакистан, Турк-

${ }^{14}$ См.: Труды Высшей школы МВД. Выпуск 3. - Душанбе, 2000. - С. 51. 
менистан, Россия и Узбекистан), а также международных неправительственных организаций (МККК, Фонд Ага Хана и др.), которые работали с таджикскими сторонами в правовой сфере разрешения конфликта наряду с политическими, социально-экономическими и гуманитарными аспектами. 